\title{
Goeie en slegte engele: 'n perspektief uit die Bybel
}

Ubi aves ibi angeli - Thomas van Aquino

F.P. Viljoen \& L. Floor

Skool vir Bybelwetenskappe en Bybeltale

Potchefstroomkampus

Noordwes-Universiteit

POTCHEFSTROOM

E-pos: sbbfpv@puk.ac.za

\begin{abstract}
Good and evil angels: a perspective from the Bible

During the second half of the 20th century a new interest in the supernatural arose. This can be seen as a reaction to prevailing rationalism and materialism. Together with this the topic of angels has received fresh attention. Attention is also given to satanism, demon possession and exorcism. This article presents a Biblical perspective on the existence and position of angels, good and evil, as a context for a broader research project on demon possession and exorcism.
\end{abstract}

\section{Opsomming}

Goeie en slegte engele: 'n perspektief uit die Bybel

Gedurende die tweede helfte van die twintigste eeu het daar 'n nuwe belangstelling in die bonatuurlike ontwikkel. Dit kan gesien word as 'n reaksie op heersende rasionalisme en materialisme. Hiermee saam het die onderwerp van engele nuwe aandag gekry. Aandag is ook gegee aan satanisme, demoonbesetenheid en eksorsie. Hierdie artikel bied 'n Bybelse perspektief op die bestaan en posisie van engele, goed en kwaad, as konteks vir 'n breër navorsingsprojek oor demoonbesetenheid en eksorsie.

\section{Inleiding}

As deel van die navorsingsprojek oor demonologie is 'n Bybelse perspektief op engele nodig. Sodoende kan die aard en aktiwiteite 
van die bose en oordeel oor die Satan en sy magte beter in konteks geplaas word.

Deur die eeue heen het mense aan sowel goeie as slegte engele geglo. Hulle woonplek, so is geglo, was die hemel (Van der Watt, 1997:93). Dit het egter verander. Engele het "verdwyn". Deur die invloed van die Aufkläring, die Verligting, het daar sogenaamd "'n ontvolking van die hemel" plaasgevind (Kuyper, 1923:9-11). Hierdie idee het ontstaan omdat die rede, die verstand, in hierdie denkklimaat oor die geloof begin heers het. Bavinck (1928:40) toon aan dat twee merkwaardige verskynsels daartoe bygedra het dat die bestaan van engele ontken is. In die agtiende eeu is die onderskeid tussen engele en mense ontken. Daarop volg in die negentiende eeu ook die ontkenning van die onderskeid tussen mense en diere. Wink (1986:1) tipeer dié situasie wat nog tot laat in die twintigste eeu geduur het: "If you want to bring all talk to a halt in shocked embarrassment ... try mentioning angels, or demons, or the devil." Hy sê verder dat iemand wat sou waag om oor hierdie wesens te praat "will be quickly appraised for signs of pathological violence".

Nogtans het hoofstroomkerke voortgegaan om aan die bestaan van engele te glo. Teoloë wat die dictum van Ernst Käsemann navolg dat apokaliptiek die moeder van die Christelike teologie is, het meer aandag aan engele gegee. Hierdie tendens is op wetenskaplike terrein gestimuleer deur die publikasie van die Dooie Seerolle en pseudepigrapha van die Ou Testament wat 'n ryk angelologie van die vroeë Judaïsme blootlê. Daar is die laaste tyd selfs mense wat beweer dat die God van die Bybel oorspronklik self 'n engel was en dat die vroegste Christologie 'n "engel-Christologie" was (Barker, 1992:358-448).

In die laaste tyd het daar hernuwe belangstelling in engele ontstaan. Daar kan twee oorsake geïdentifiseer word:

- Die moderne mens is moeg vir verstandsgodsdiens. Daar is weer belangstelling in die okkulte en die mistiek. Daar kan gewys word op die invloed van die Oosterse godsdienste (Noll, 1998:12).

- Engeleverskynings geniet baie belangstelling. 'n Nederlandse dokter het deur middel van die media ondersoek ingestel na manifestasies van engele in sy land. Hy het so baie reaksies gekry dat hy spottenderwys opgemerk het dat dit lyk of daar in Nederland alleen meer engeleverskynings plaasgevind het as in die hele Bybel (Selderhuis, 2002:13). In Duitsland het ' $n$ 
omvangryke boek oor engele by Uitgewery Herder verskyn. Aan die hand van afbeeldings toon die skrywer watter beelde mense deur die loop van eeue van engele en demone gevorm het. Hierby is dit opvallend dat engele in baie gevalle as vroue met vlerke geteken is. Die gevalle engele is daarenteen nie so saggeaard en lieftallig afgebeeld nie. Die duiwel en demone lyk op baie afbeeldings soos vreesaanjaende monsters. ' $n$ Middeleeuse houtsnywerk met die naam Tentationes daemonis beeld op 'n weersinwekkende manier die duiwel as versoeker van 'n sterwende uit (Vorgrimler, 2001:184).

Aan die begin van 2004 het dr. L.F. de Graaff by prof. dr. A. van de Beek van die Vrije Universiteit sy proefskrif oor die engele verdedig (De Graaff, 2004). Hy het aangetoon dat engele steeds meer uit kerke en die teologie verdwyn het. Volgens De Graaff is daar in esoteriese kringe wel besondere belangstelling vir engele, maar daar gebeur presies waarteen Augustinus (Augustinus, 1947:11.13) gewaarsku het: engele as sodaning word vereer en nie gerespekteer ter wille van die take wat hulle van God ontvang het nie. Engele het wel 'n bepaalde status, maar hulle status word bepaal deur die taak wat hulle verrig. Calvyn was, in navolging van Augustinus, redelik terughoudend in sy kommentaar oor engele. Hy het meestal net klem laat val op die take wat hulle moet verrig (Calvyn, 1980 [1559]:1.14). H. Bavinck (1928) volg Calvyn hierin na. De Graaff is nie so gereserveerd in sy skrywe oor engele nie. Hy sluit hom teenoor Bavinck by Kuyper (1923) aan wat ook nie heeltemal vry was van spekulasies oor wat engele doen nie. De Graaff gaan verder in sy spekulasie oor engele. Hy sien engele selfs as middelaars tussen die mens en God (De Graaff, 2004:202). De Graaff toon wel oortuigend aan dat dit goed is dat daar opnuut belangstelling vir engele is. Uit sy boek blyk dit egter ook dat ' $n$ mens maklik met onbybelse spekulasies kan weghardloop (De Graaff, 2004:196).

Hoewel daar in die laaste tyd heelwat oor engele gepraat word, doen baie dit half tong-in-die-kies, aangesien hulle die bestaan van engele nie werklik ernstig opneem nie (Fox, 1997:112). Heel gepas maak Noll (1998:11) die opmerking: "To theologize about angels is a most dubious undertaking in our day. But to ignore the subject of angels is to miss one of the comeback stories of the century."

Die doel van hierdie artikel is in die eerste plek om in die lig van historiese en Bybelse gegewens 'n verantwoordelike oorsig te bied van engele in die algemeen. Hierdie inligting bied die konteks vir 'n breër ondersoek oor demone en demoongekweldheid. Die 
ondersoek van hierdie artikel is nodig vanweë wisselende belangstelling in en beskouing van engele wat in die een uiterste uitloop op verregaande spekulasies oor engele en in die ander uiterste neerkom op die ontkenning van die bestaan van engele. In hierdie artikel word gepoog om 'n Skrifverantwoorde standpunt oor engele te stel.

\section{Historiese oorsig van standpunte oor engele}

Gesprekke oor engele is so oud soos die teologie self. Angelologie funksioneer grootliks as 'n weerhaan wat die rigting van verskeie winde van lering deur die geskiedenis van Christelike teologie aandui. Vervolgens word 'n kort historiese oorsig van Christelike nadenke oor engele gebied.

\subsection{Klassieke angelologie}

In die klassieke angelologie van die Westerse en Oosterse kerke staan twee teoloë se standpunte uit, naamlik dié van Augustinus (354-430) in die Weste en van Pseudo-Dionisius (sesde eeu) in die Ooste. Hierdie twee onderskeie strome van die Weste en Ooste vloei uiteindelik saam by Thomas Aquinas (1225-1274).

Augustinus verbind engele direk aan God se verlossingsplan in Christus. In teenstelling met heidense veelgodendom wat met engeleverering gepaard gegaan het, verklaar Augustinus dat engele nie aanbid mag word nie (Stander, 1997:88). Hoewel hy aandag gee aan die aard van engele, fokus hy op die funksie van die engele. Volgens Augustinus het die Satan en die bose engele tydens die skepping gekies om op hulleself te vertrou en hulle eie natuur te vereer in plaas daarvan om God te vereer. In teenstelling met die bose engele het die goeie engele guns by God gesoek. Augustinus vermy die dualistiese idee dat die bose ewig is en dat engele onafhanklik van God voor die skepping geleef het (Augustinus, 1947:11.13). Augustinus se beskouing het normatief geword vir die Westerse Christendom.

Pseudo-Dionisius het in sowel die Oosterse as Westerse kerk 'n groot invloed op die leer van engele gehad. Hy was 'n Neo-Platonis wat waarskynlik in Sirië gewoon het. Pseudo-Dionisius onderskei en orden die engele in nege range, waarvan die eerste die naaste aan God en die mees verhewe is, en die laaste die naaste aan mense en die minste verhewe is. Dienooreenkomstig maak hy 'n lys van die range vanaf die meeste tot die minste verhewe: serafs, gerubs, trone, heerskappye, owerhede, magte, aartsengele en engele. 
Volgens hom is net die laagste drie range by mense betrokke. Deur engeleverering word hierdie engele gunstig gestem om mense te help in hulle reiniging, verligting en vervolmaking. Deur die hulp van engele vorder 'n mens deur die rangordes van die engele op jou pad van saligheid (Stander, 1997:70). Die Oosters ortodoksie beskou dit as die proses van heiligmaking waarvan die uiteinde gemeenskap met die goddelike natuur is (Louth, 1989:38-43). Dit is teen hierdie beskouing dat Paulus in Kolossense ernstig waarsku (vgl. Viljoen, 2002:70).

Thomas Aquinas bied 'n sintese van die klassieke angelologie en gebruik Augustinus en Pseudo-Dionisius as belangrike bronne. Thomas beroep hom op Psalm 104:4 (“U wat die winde u boodskappers maak") as hy oor die natuur van engele skryf in reaksie op die materialistiese filosofie van sy tyd. Hy toon aan dat engele geen materie het nie, maar gees is. Hy beskryf hulle as die boodskapperwinde van God (Aquinas, 1991: 50.1).

\subsection{Reformasie}

Die Reformatore is meer versigtig om hulle oor engele uit te laat. Teenoor die Middeleeuse teoloë, soos Thomas Aquinas, wat baie klem op die geestelike natuur van die engele gelê het, plaas die Reformatore eerder klem op die funksie van die engele. Vir die doel van hierdie artikel word net kortliks na die standpunt van Calvyn verwys.

Calvyn is dit eens met die klassieke standpunte oor engele, naamlik dat hulle beslis bestaan, dat hulle geestelik is, dat hulle geskape is en dat die engele wat met die mensdom in stryd is, in sonde geval het. Deur by die sola Scriptura-beginsel te bly, weerhou Calvyn hom egter van die spekulasies van die Middeleeuse teoloë dat engele mistieke gidse is wat mense verlig. Hy beroep hom op Hebreërs 1:14 ("Is hulle dan nie almal geeste in diens van God, wat Hy uitstuur om dié te dien wat die saligheid gaan beërf nie?"). Calvyn beskou engele as boodskappers van God se verlossing en troos vir mense. In teenstelling met Pseudo-Dionisius leer hy dat 'n mens nie langs die weg van engeleverering en erkenning van hulle range tot saligheid vorder nie, maar slegs deur geloof in Jesus Christus. Hoewel engele as boodskappers van God gerespekteer moet word, mag hulle nie vereer word nie. God alleen kom al die eer toe (Calvyn, 1980 [1559]:1.14). 


\subsection{Modernisme}

Aangesien die "lig van menslike rede" deur die Modernisme en die Aufklärung as finale maatstaf vir waarheid beskou word, is daar binne dié denkraam nie plek vir engele nie. Volgens die Modernisme moet die geloof aan engele en demone as 'n religieuse aangeleentheid "of the power of spirit over matter" (Noll, 1998:22) beskou word. Geloof kan egter nie die rasionele toets deurstaan nie en is daarom irrelevant as dogma. Binne hierdie konteks hanteer Schleiermacher engele en demone as 'n appendiks by die dogma oor die skepping en merk op: "Christ and the apostles might have said these things about angels without having had any real conviction of the existence of such beings ... as, for example, we might talk of ghosts and fairies" (Schleiermacher, 1928:42). Schleiermacher se kriterium sou eventueel tot Bultmann se ontmitologiseringsprogram lei (vgl. Bultmann, 1984:2-4). Ook in modernistiese verband het die Romantiek die werklikheid van engele ontken, deur hulle bloot as simbole van sentimentele liefde te beskou. Die Romantiek het ook bose engele, onder andere in die vorm van Frankenstein, geskep (Noll, 1998:22).

\subsection{Postmodernisme}

Binne die postmoderne wêreldbeskouing het daar opnuut ruimte gekom vir voorveronderstellings wat op 'n manier verband hou met geloof. Binne so 'n konteks word die Bybelse openbaring oor engele aanvaar sonder om dit rasioneel te probeer verklaar of dat daar natuurlike korrelasie hoef te bestaan. Tog het die postmodernistiese gees ook ruimte geskep vir verregaande spekulasies. In die kringe van die New Age-beweging is daar 'n obsessie oor engele. Aanhangers van hierdie beweging poog om met engele kontak te maak, aangesien elke mens 'n engel as persoonlike geestelike gids sou hê. Hierdie engele is na bewering toegankliker as God (Joubert, 1997b:108). Mense van die New Age-beweging bid tot engele in hulle poging om persoonlik kontak te maak met hulle persoonlike beskermengele. Hulle glo ook aan bepaalde engele waarmee ' $n$ mens moet kontak maak vir genesing (genesingsengele) of vir troos (vertroostingsengele) (Joubert, 1997a:53).

\section{Bybelse getuienis oor engele}

In die lig van bogenoemde wisselende opinies oor engele, word daar vervolgens gevra na die Bybel se getuienis oor engele. Verwysings na engele en ander hemelse wesens kom ongeveer 258 keer in die Bybel voor. Daarvan bevat die Ou Testament 63 
verwysings en die Nuwe Testament veel meer. In die Nuwe Testament word sowat 195 keer na engele verwys: in die Evangelies 24 keer, in die boek Handelinge 21 keer, in Paulus se briewe 28 keer en in die Openbaring van Johannes byna op elke bladsy (Human, 1997:33).

Sommige navorsers is van mening dat die geloof aan engele en geestelike wesens in die Bybel die direkte invloed van die omliggende heidense gelowe sou wees. Hierdie engelegeloof het veral met die krisis van die ballingskap Israel se godsdiens en geskrifte (Ou Testament) binnegedring en tot volle ontwikkeling gekom in apokaliptiese Judaïsme (Human, 1997:38). Ten spyte van rabbi's se pogings om hierdie invloede teë te werk, het die geloof aan engele tog posgevat. In die tyd van die Nuwe Testament is Israel so deur vreemde godsdienstige idees oorspoel, dat die geloof aan geestelike wesens in baie gemeenskappe aanvaar is. Van die apostels het dié geloof probeer onderdruk, maar in die Evangelies, die sogenaamde deutero-Pauliniese Efesiërs en Openbaring, het die geloof in engele hoogty gevier (vgl. Noll, 1998:29). Wie hierdie beskouing van die Bybelse tekste aanvaar, besluit op grond van hipoteses watter getuienisse van die Bybel betroubaar is en watter misleidend.

Wanneer 'n mens egter die getuienis van die Ou en Nuwe Testament aanvaar, is so 'n benadering nie moontlik nie. Dit is inderdaad so dat daar in sekere tye en boeke groter konsentrasie verwysings na engele is. In die Ou Testament sowel as in die Nuwe Testament word die werking van engele beskryf. Engele is hemelse wesens, lede van God se hofhouding wat Hom dien en prys (Job 1:6; Jes. 6:2 e.v.). Behalwe vir hulle taak in die hemel, is engele ook op aarde werksaam. Hulle is getuies by die skepping (Job 38:7). Hulle tree op as bodes of gesante van God. Engele moet in opdrag van God dikwels allerlei take op aarde uitvoer. Enkele voorbeelde uit die Bybel word genoem:

- Engele bewaak die toegang tot die paradys (Gen. 3:24).

- Engele hou by Jakob se bed op die grond die kontak met die hemel oop (Gen. 28:12).

- Josua word deur engele ondersteun (Jos. 5:13 e.v.).

- Die pes-epidemie by Jerusalem word deur 'n engel gestuit (2 Sam. 24:16-17).

- Daniël word deur 'n engel bemoedig (Dan. 10:5-11). 
- 'n Engel kondig die geboorte van Christus aan en 'n koor van engele sing by daardie gebeurtenis (Luk. 2:9-15).

- In Getsemane verskyn 'n engel uit die hemel om Jesus te versterk (Luk. 22:43).

- Engele is aktief by die opstanding van Jesus betrokke (Matt. 28:2; Luk. 24:4).

- By Jesus se hemelvaart kom twee engele die dissipels toespreek (Hand. 1:10).

- Petrus word deur 'n engel uit die tronk bevry (Hand. 12:7-9).

- Paulus word op die skip in die storm deur 'n engel bemoedig (Hand. 27:23-24).

\subsection{Verhouding tussen God en engele}

In die Semitiese en Griekse mitologieë word gode en geestelike wesens met mekaar geïdentifiseer. Binne die goderyk bestaan daar 'n hiërargie waarvolgens die hoër gode deur die ondergeskikte gode gerespekteer en vereer moet word. Die oppergod is nie die almagtige God nie. Dit is ook nie so dat die ondergeskikte gode slegs volgens die almagtige God se wil en toestemming optree nie. Die oppergod eis ook nie dat hy alleen vereer moet word nie. Daar bestaan voortdurende onderlinge stryd in die goderyk om die gode se posisies binne die rangorde te bepaal (Smart, 1984:33).

In teenstelling met hierdie heidense veelgodendom handhaaf die Bybel 'n monoteïstiese perspektief. As enigste skepper en God is die Here verhewe bo alles en almal wat Hy geskep het. Daar bestaan geen ryk bo of naas Hom wat sy absolute soewereiniteit kan beperk nie. Hy is volkome onderskeie en anders as die skepping: "Luister, Israel, die Here is ons God, Hy is die enigste Here" (Deut. 6:4). Le Roux (1997:13 e.v.) redeneer op grond van Israel se monoteïsme dat die voorkoms van engele in die $\mathrm{Ou}$ Testament die gevolg is van Babiloniese, Persiese en Hellenistiese invloede op Israel se godsdiens - dit is volgens hom die rede waarom geskrifte wat in die tyd van hierdie oorheersings geskryf is, skielik van die engele wemel (Le Roux, 1997:26). Hy beweer verder dat wanneer die volk naby die Here geleef het, hulle geen behoefte aan engele gehad het nie (vgl. ook Human, 1997:33). Wanneer hulle egter ver van God geleef het, het hulle die heidense idees van engele, demone en die Satan oorgeneem. Die vertrekpunt wat aan Le Roux se standpunt ten grondslag lê, is dat die teks van die Ou 
Testament deur heidense idees beïnvloed is. Wie hierdie teks vandag lees, moet hierdie invloede identifiseer en hulle nie daardeur laat mislei nie.

Dit is inderdaad so dat die omliggende volke aan talle goeie en slegte geeste geglo het. 'n Algemene afbeelding in die buite-Bybelse antieke pantheons wat in Egipte, Mesopotamië en Kanaän gevind is, is dié van 'n goddelike raad. Gode word uitgebeeld as raadslede wat voorvalle beoordeel en toestemming verleen vir militêre ekspedisies (Noll, 1998:35). Die parallel van hierdie beeld kom wel in die Bybel voor, naamlik dat God deur engele omring word. Daar is egter 'n belangrike verskil. In die Ou Testament word die beeld telkens gebruik om die uniekheid van die Here te beklemtoon: "Wie in die hemel kan met die Here vergelyk word? Wie onder die hemelwesens is soos die Here? Hy is God, vir Hom het die hemelse vergadering ' $\mathrm{n}$ heilige ontsag. Hy is magtig, gevrees onder almal rondom Hom" (Ps. 89:7-8). In aansluiting by die onvergelyklike soewereiniteit van God, maak die Bybel dit duidelik dat die Here niemand nodig het om vir Hom advies te gee nie: "... wie kan sy raadgewer wees? Vir wie raadpleeg Hy dat dié Hom sou leer wat om te doen? Wie leer Hom en onderrig Hom dat Hy met insig kan optree?" (Jes. 40:13-14).

Engele staan in diens van God. Hierdie diens is tweevoudig van aard, naamlik 'n diens in die hemel en 'n diens op aarde. In die hemel is die engele geroep om rondom God se troon te wees en Hom dag en nag te prys (Jes. 6:2, 3; Op. 5:11). Op aarde was en is daar vir hulle 'n drievoudige taak:

- Begeleiding by keerpunte in die heilsgeskiedenis: Jesus se geboorte, sy opstanding en sy hemelvaart.

- Stryd teen bose magte (Dan. 10:13).

- Diens aan die gelowiges (Hebr. 1:14), naamlik in sterwensbegeleiding (Luk. 16:22), in die erediens (Hebr. 12:22-24) en algemene begeleiding en bewaring van God se kinders (Ps. 91).

Dit blyk dat die Bybel erken dat engele bestaan, maar dat hulle duidelik van God onderskei moet word. Deurgaans word die engele as dienaars en boodskappers van God beskryf. In die lig van hierdie Bybelse gegewens blyk dit dat daarteen gewaak moet word om, soos Thomas Aquinas, die natuur van engele losstaande van hulle funksie te definieer. Aan die ander kant moet ook gewaak word teen die beskouing van die Verligting wat engele gedegenereer het tot naïewe beeldspraak of romantiek. 


\subsection{Engele en die skepping}

Volgens die Babiloniese en Mesopotamiese skeppingsmites het gode van 'n laer orde tydens die "skepping" in opstand gekom teen die magte van die hemel, aarde en die see. Hierdie konflik het tot 'n hiërargie in die natuur en goderyk gelei. Die chaotiese gode is tot die onderwêreld ingeperk, maar van tyd tot tyd sou hulle die stabiliteit van die hiërargie en die natuur uitdaag. Volgens hierdie mites is die mensdom ondergeskik aan die gode en is hulle verplig om die gode te dien. Die engele word met die goderyk vereenselwig (Lambert, 1975:55-59).

Hierdie panteïstiese, mitiese wêreldbeeld van die omliggende heidene verskil van die Bybelse wêreldbeeld. God is transendent. $\mathrm{Hy}$ is die skepper van die hemel en aarde. Geen gode hou vir Hom 'n bedreiging in nie: "Al die gode van die volke is niks: dit is die Here wat die hemele gemaak het" (Ps. 96:5). Hy is die skepper van alle sigbare en onsigbare dinge, trone, heerskappye, owerhede en magte (Kol. 1:16; vgl. ook Viljoen, 2002:89). Ook engele is dus deur God geskep.

Die skeppingsverhaal in Genesis 1 verwerp die heidense mitologie van 'n hiërargiese stryd in die geestesryk (van gode en engele) tydens die "skepping". Die openingsin, "In die begin het God die hemel en die aarde geskep" (Gen. 1:1), kanselleer die heidense tema van die geboorte van gode. Die God van die Bybel is nie gebore nie. Hy is van ewigheid af daar. Die skepping het nie uit 'n vorige realiteit ontwikkel nie. Hyers (1984:81-102) toon aan hoe daar in die skeppingsverhaal met elke skeppingsdag nog 'n afgod van die heidendom onttroon word: Die eerste dag is die gode van lig en duisternis verwerp; die tweede dag die gode van die lug en die see; op die derde dag die gode van die plantegroei; op die vierde dag die son, maan en ander stergode; op die vyfde dag word daar uit die diereryk enige assosiasie met goddelikheid uitgeskakel, maar op die sesde dag word die mens na die beeld van God geskape. Dit is veelseggend dat daar in hierdie skeppingsverhaal geen melding van engele gemaak word nie.

\subsection{Identiteit, aantal en rangorde van engele}

Die Babiloniese ballingskap word gewoonlik beskou as die waterskeidingsperiode waartydens die Joodse monoteïsme sy hoogtepunt bereik het. Apokaliptiese angelologie het in dié tyd ook gefloreer. Die engele wat vroeër as God se boodskappers beskryf is, se identiteit word nou duideliker gestel. Die enigste twee engele wat by 
die naam geïdentifiseer word, is Gabriël en Migael en daar word die meeste in die apokaliptiese deel van die boek Daniël na hulle verwys (Raphael word in die apokriewe boek van Tobit genoem). Die vroegste lys van aartsengele kom in die boek van 1 Henog voor en word as Migael, Sariël, Raphael en Gabriël geïdentifiseer (1 Henog 9:1). Later word 'n lys van sewe aartsengele gegee (1 Henog 20).

In die Ou Testament word Migael geïdentifiseer as die hoogste figuur in die engeleryk (Dan. 10-12). Die glans en die heerlikheid van die aartsengele word in die Bybel beskryf, maar altyd in onderskeid met die heerlikheid van God. In Esegiël 1:26-28 word die heerlikheid van God beskryf teenoor Esegiël 8:2 waar die heerlikheid van die aartsengel beskryf word. Soortgelyk is ook die geval in Daniël 7:9-10 (die heerlikheid van God) en Daniël 10:5-6 (die heerlikheid van die aartsengel). In Openbaring word onderskeidelik die heerlikheid van God (Op. 4:2-6), van Christus (Op.1:1216) en die engel (Op. 10:1-3) beskryf. Die belangrike onderskeid is dat die engel nie aanbid mag word nie. Die lof kom God toe.

Dit is duidelik dat die Christendom se beeld van God en van die engele aansluit by dié van die Ou Testament. Die beskrywing in Openbaring 4 kom ooreen met die monoteïstiese beeld van die $\mathrm{Ou}$ Testament. God is enig, Hy is gees, Hy is heilig, Hy is die Skepper en $\mathrm{Hy}$ is die Here. God is egter nie alleen nie. Hy word omring deur ander geestelike wesens en heiliges wat gesag van God ontvang het. God alleen is waardig om al die lof te ontvang en Hy aanbid niemand nie (Viljoen, 2003:222). Soos die maan genereer engele nie hulle eie lig nie. Soos wat dit onmoontlik is om in die son in te kyk, so kan 'n mens deur die engele indirek iets van die glorie van God raaksien, soos die maan iets van die glans van die son weerkaats.

Uit Bybelse getuienis blyk dat die aantal engele oorweldigend is (Matt. 26:53; Op. 5:11). Deur die eeue is daar telkens pogings aangewend om die rangorde van engele te bepaal. Soos hierbo aangetoon het Pseudo-Dionisius Aeropagita omstreeks 500 n.C. in sy werk De hierarchia coelesti die engelewêreld in nege (drie maal drie) groepe geklassifiseer: die hoogste drietal is die serafs, die gerubs en die trone. Dan volg in 'n laer orde die tweede drietal: die heerskappye, magte en kragte. Daarna volg die derde drietal: die vorste, aartsengele en engele (vgl. Human,1997:96). Om so 'n onderskeid uit die Bybel af te lei, is egter geforseerd. Tog het teoloë soos Kuyper (1923) met Skrifberoep die volgende drie groepe en klasse van engele onderskei. 
Die eerste groep is die aartsengele. Die Bybel noem twee, naamlik Gabriël en Migael:

- Gabriël se naam beteken "Man van God" of "Held van God". Van hom word in Lukas 1:19 gesê: " ... wat in diens van God staan”. Waarskynlik is hy die hoogste in rang. Hy is naby God en word as God se boodskapper gebruik (Dan. 8:16; 9:21; Luk.1:19,26). Godet (1986:29) noem hom "die hemelse evangelis". In die Ou Testament kondig Gabriël vir Daniël die koms van die Messias aan (Dan. 8:16; 9:21). In die Nuwe Testament bring Gabriël aan die priester Sagaria die berig oor die geboorte van Johannes die Doper (Luk. 1:19) en aan Maria die berig oor die geboorte van Christus (Luk. 1:26).

- Die tweede aartsengel is Migael (Jud. :9). Die betekenis van sy naam is 'n vraag: "Wie is soos God?" Die Hervormers, Luther en Calvyn, het gedink dat die naam Migael 'n ander naam is vir Christus. Leahy (1990:17-18) toon aan dat so 'n opvatting nie die toets van die Bybel deurstaan nie. Die Bybel berig dat Migael bedrywig was toe die ryk van die lig met die ryk van die duisternis gebots het (Dan. 12:1; Jud. :9; Op. 12:7). Hy tree op as 'n veggeneraal teen allerlei bose magte.

By die wederkoms van Christus sal daar 'n bevel gegee word en die stem van 'n aartsengel sal gehoor word (1 Tess. 4:16). Wie hierdie engel is, word egter nie vermeld nie. Sommige Skrifverklaarders is van mening dat hierdie aartsengel Migael is. Hy begelei Jesus by sy tweede koms. 1

'n Tweede groep engele is die gerubs en serafs. Die betekenis van die woord gerub is nie heeltemaal duidelik nie. Waarskynlik is die woord gerub afgelei van 'n werkwoord waarin die betekenis van krag of mag tot uitdrukking gebring word (Kuyper, 1923:145). Die gerubs (of gerubyne) is engele wat in diens van God staan. Hulle het verskillende take om te verrig. In die eerste plek is hulle die bewakers van God se heiligheid en ten tweede is hulle verteenwoordigers van sy heerlikheid. Die twee goue gerubs bokant die ark wat hulle vlerke oor die ark uitsprei, tree as bewakers van die troon van God op. God het aan die gerubs opdrag gegee om die

1 Volgens Joodse tradisie is daar nog vyf ander aartsengele: Jeremiël, Ramiël, Rafaël, Uriël en Fanuël (Schoeman, 1997:40-43). Ook hulle name eindig op -ël, wat 'n verwysing is na God. Oor hulle bestaan is daar egter nie getuienis in die Bybel nie. 
paradys te bewaak (Gen. 3:24). Hulle tree op as draers van die troon van God (Eseg. 9:3; 10:1-22). Wanneer God afdaal na die aarde word Hy deur gerubs begelei (Ps. 18:11). Die profeet Esegiël sien dat God op 'n troonwa ry wat deur gerubs gedra word (Eseg. 1:8). Die gerubs vervul 'n belangrike taak in die tabernakel en later in die tempel. In God se tent en later in God se huis woon die Here tussen die gerubs (Ps. 99:1).

Onder die tweede groep engele val ook die serafs (of serafyne). Hulle word net in Jesaja 6:2-3 genoem. Hulle naam is afgelei van 'n woordstam wat om te brand beteken. Hulle staan in 'n besondere verhouding tot die heiligheid van God. Hulle brand vir die heiligheid van God en daarom brand hulle die onheiligheid weg van die profeet wat Jahwe mag aanskou. Die gerubs simboliseer die wet van God, terwyl die serafs God se genade voorstel (Kuyper, 1923:149).

Die derde groep wat Kuyper (1923:155) onderskei, is die trone, heerskappye, owerhede en magte (Kol. 1:16). Dit is blykbaar nie Paulus se bedoeling om in Kolossense 1:16 'n sistematiese klassifikasie van hemelse engelemagte te gee nie (vgl. Viljoen, 1986:119). Die apostel wil net aan sy lesers duidelik maak dat daar in die wêreld engelemagte bestaan wat deur God geskape is. Hulle is aan Christus onderwerp en staan in sy diens. Dit wil voorkom asof daar in die hemelse sfere iets van 'n militêre struktuur onder die engele bestaan. Daar word geregeer, daar is gesag en daar word mag uitgeoefen (Kuyper, 1923:157). Daar is blykbaar in die engelewêreld 'n sekere mate van gesag wat in kleiner of groter kring uitgeoefen word. In Efesiërs 3:10 beperk Paulus owerhede en magte tot die hemelse geweste. Om soos Karl Barth (1936:534-536) in owerhede en magte maatskaplike en sosiale strukture, bepaalde samelewingsverbande of politieke en kulturele kragte te sien, is egter geforseerd en nie Bybels verantwoord nie (vgl. Floor, 1998:131). Berkhof volg die lyn van Barth. Hy kom tot die konklusie dat Paulus met magte nie engele bedoel het nie. Berkhof beskou magte as onpersoonlike "levensverbanden" (Berkhof, 1952:25). Uit die verskillende benaminge kan wel iets anders afgelei word. God se engele moet ons beskou as belangrike en magtige faktore in die geskiedenis van die kerk en die wêreld. 
'n Moontlike vierde groep word deur Paulus 2 in 1 Timoteus 5:21

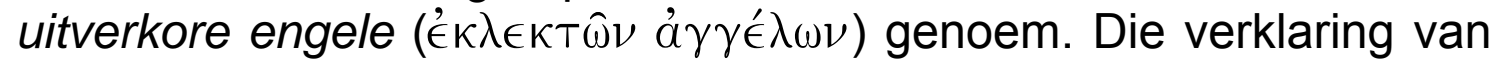
wat hierdie soort engele is, loop wyd uiteen. Blauw sien in hulle engele wat God oorgegee het aan die duisternis (Blauw, s.a.:162). As dít Paulus se bedoeling was, sou hy waarskynlik eerder die kwalifikasie onheilig gebruik het. Die formulering heilige engele kom nie elders in die Bybel voor nie. Ons vind wel hierdie uitdrukking in die apokriewe en pseudo-epigrafiese geskrifte, byvoorbeeld in Henog 39:1. Die woord heilig as 'n kwalifikasie vir engele dui eerder op 'n besondere voorreg om in God se diens te staan. Ridderbos is

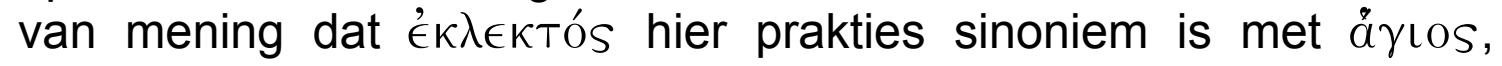
aangesien in Markus 8:38 en Judas :14 na engele as heilige engele verwys word (Ridderbos, 1967:144).

\subsection{God gebruik engele tot behoud van mense}

Die skrywer van die brief aan die Hebreërs wys daarop dat engele geeste is wat in diens van God staan. Hulle word deur God uitgestuur om diegene te dien wat die saligheid gaan beërf (Hebr. 1:14). Die skrywer maak onderskeid tussen die diens van Christus en die diens wat engele moet verrig. Christus se diens is heilsbemiddelend. Hy bedien God se heil aan die wêreld. Hy verlos mense van die sonde. Hy verwerf vir die gelowiges die saligheid ( $\sigma \omega \tau \eta \rho i ́ \alpha)$. Die diens van die engele het nie hierdie heilskarakter nie (Van Oyen, 1954:22). Hulle bystand aan die gelowiges lê op 'n ander vlak. Engelediens hou wel verband met die saligheid, maar hulle het egter die opdrag om te sorg dat die gelowiges die saligheid werklik sal beërwe. Hulle moet toesien dat die gelowiges by hulle eindbestemming uitkom.

Wil 'n gelowige staatmaak op engelebeskerming dan moet hy/sy hom/haar aan Jesus Christus onderwerp (Calvyn, 1972 [1549]:27). Die bystand van engele mag van God afgesmeek word, want God stuur hulle. Hierdie hulp word soms bewustelik en soms onbewustelik deur gelowiges ondervind. 


\section{Bose engele}

\subsection{Satan en sondeval in die engeleryk}

Talle teoloë staan skepties teenoor die bestaan van 'n persoonlike duiwel (vgl. Van Aarde, 1987:22). Hulle verkies om die bose as 'n abstrakte entiteit te beskou en die Satan as simbool van die kwaad. Dikwels word onderskei tussen natuurlike kwaad (plae), morele kwaad (sonde) en metafisiese kwaad (onvolkomenheid) (Noll, 1998:119). Die Bybel getuig egter van die bestaan van die duiwel en die bose. In navolging van Bultmann erken talle teoloë tans dat die Satan en die bose deel vorm van die Bybelse wêreldbeeld. Hulle verwerp egter hierdie wêreldbeeld, aangesien hulle dit as ongeloofwaardig beskou (Van Aarde, 1987:37).

David Friedrich Strauss, die vader van teologiese liberalisme, het hierdie benadering tot sy uiterste konsekwensie gevoer. Volgens hom hang die realiteit van Christus se persoon saam met dié van die Satan. Hy redeneer dat dit onmoontlik is om persoonlik aan Christus te dink, maar onpersoonlik oor die Satan.

If Christ has come to destroy the works of the Devil, then he need not come if there is no Devil. If there is no Devil but only a personification of the principle of evil, well and good: it is enough for Christ also to be an impersonal idea. (Strauss, 1906[1840]:15).

Historiese en Bybelse getuienisse kan egter nie só maklik ontken word nie.

'n Groot ontwikkeling van die na-Babiloniese tydperk is dat daar tussen goeie en bose engele onderskei is, hoewel die idee van die duiwel reeds van die begin van die Ou Testament af bekend was. 3 Hoewel die Ou Testament oor die identiteit van die slang in Eksodus 3 swyg, verbind talle tekste in die Nuwe Testament die Satan met "die slang van ouds" (Op. 12:9; vgl. 2 Kor. 11:3; Joh. 8:44; 1 Joh. 3:8). Die bose is egter geheel en al ondergeskik aan God.

Die gedagte van 'n sondeval in die engeleryk wat slegs implisiet in voor-eksiliese tekste voorkom, word 'n belangrike tema in Joodse

31 Henog vermeld ook twintig gevalle engele wie se name met astrologiese en meteorologiese verskynsels verbind word. Vroeë apokaliptiese tekste noem ook die name van twee duiwels wat onder andere bekend sou staan as Azazel, Belial en Satan (Noll, 1998:43). 
apokaliptiese literatuur. Die verhaal van Henog maak 'n kategoriese onderskeid tussen die geeste wat staande gebly het en die wat in sonde geval het. Sataniese aktiwiteit word in die apokaliptiese literatuur onderliggend aan tragiese teenslae geïdentifiseer (Jubilee 17:15-18:13), soos ook reeds in die verhaal van Job beskryf is. Volgens die Evangelies het Jesus ook na die sondeval van Satan en sy engele verwys (Luk. 10:18; Matt. 25:41). Die sondeval in die engeleryk word in die Nuwe-Testamentiese apokalips (Openbaring) uitgebreid weergegee. 'n Deel van die engele het teen God in opstand gekom. Volgens Openbaring 12:4 was dit moontlik 'n derde van die totale engelemag. Volgens Johannes 8:44 het hulle uit hulle

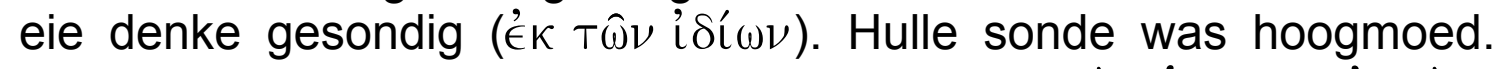

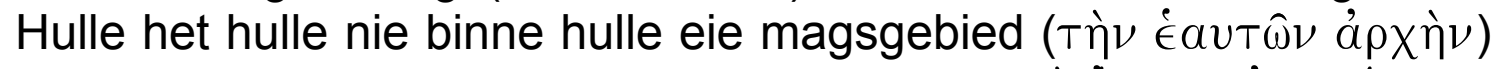

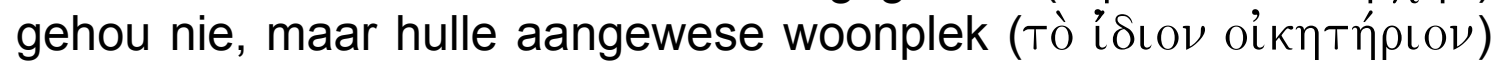
verlaat (Jud. :6). Wat met hierdie aangewese woonplek bedoel word, word gewoonlik aan die hand van Deuteronomium 32:8 verklaar. Volgens die Septuagint se weergawe van hierdie teks, het God aan elke volk 'n engel toegewys om daardie volk te bestuur. Sommige engele was egter nie tevrede met die plek wat God vir hulle aangewys het en met die posisie waarin God hulle geplaas het nie. Volgens die Bybel is die verskil van die sondeval van die engele met dié in die mensewêreld daarin geleë dat die mens deur verleiding gesondig het (Gen. 3), maar die engele het uit hulleself, uit hulle innerlike oortuiging gesondig (Leahy, 1990:13)4 .

\subsection{Ryk van die duisternis}

Die wêreld van die bose engele is goed georganiseer. Die demoniese organisasie vertoon baie ooreenkomste met dié van die goeie engele. Paulus skryf in Efesiërs 6:12 vir sy lesers teenoor watter vyand hulle staan: owerhede, magte, wêreldheersers van die duisternis en bose geeste in die lug. Dit herinner aan die woorde van Luther: "Die duiwel is die aap van God" (Stolk, 1964:15).

Soos die heilige engele onder die gesag van God staan, so is die bose engele onderworpe aan die gesag van hulle leier - 'n hoë engel wat in die Bybel met verskillende name genoem word: Duiwel, Satan, Apollion, Beleal, Beëlsebub, owerste van die mag van die lug (Ef. 2:2) en die groot draak (Op. 12:3). (Vgl. Schilder, 1929:3-86 wat 'n uitgebreide beskrywing van die name van die Satan bied.)

4 Die Islam glo ook in gevalle engele. Hulle is oortuig dat elke mens begelei word deur twee engele: aan sy regterkant is daar 'n goeie engel en aan sy linkerkant 'n slegte engel (Schoeman, 1997:22). 
Teenoor die koninkryk van God staan die ryk van die duisternis.

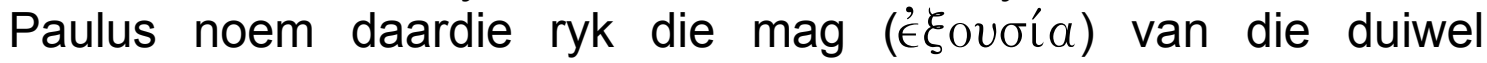
(Kol. 1:13). In die lig van bogenoemde opmerking van Luther, moet dit bloot as 'n pseudo-ryk gereken word.

Hoewel die werk van die duiwel onsigbaar is, is dit nie onwaarneembaar nie. Paulus skryf in 2 Korintiërs 2:11: "Ons ken sy planne maar alte goed." Vir planne word in die Griekse teks die

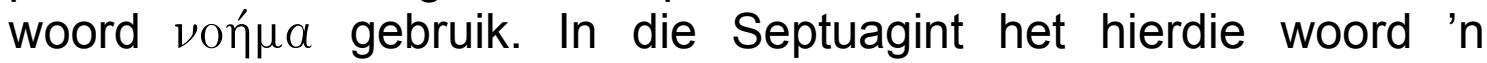
negatiewe konnotasie: "It means evil intention, plot" (Sir. 1:11; Bar. 2:8; 3; Mak. 5:30; Harder, 1978:125). Die wyse waarop Satan optree, beskryf Paulus onder andere in Efesiërs 2:2-3. Die duiwel beïnvloed die lewenswandel van baie mense. Hulle word gestuur en gemanipuleer. Die invloed geskied tweërlei, naamlik volgens die geskiedenis van hierdie wêreld en volgens die owerste van die mag van die lug. Die sondige lewenswandel word deur die duiwel gemanipuleer "volgens die eeu van hierdie kosmos". In 'n van-Godafvallige wêreld beweeg die mense volgens bepaalde sondige riglyne en norme. Dit is die duiwel wat dit alles manipuleer. Daar sit iets tiranieks in: so 'n samelewing oefen 'n kontrolerende invloed op mense uit. Die lewensvisie en gedragspatrone van mense kan maklik deur die duiwel beïnvloed word. Paulus het dit duidelik waargeneem in die samelewing waarin hy geleef en gewerk het.

Paulus noem die duiwel die owerste $(\alpha ́ \rho \chi \omega \nu)$ van die mag van die

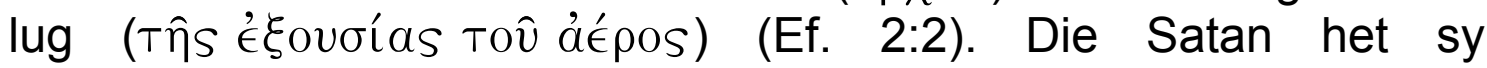
operasiebasis nie ver van die wêreld verwyder nie. Sy demoniese invloed manifesteer op twee terreine: die menslike wil en die menslike verstand. Die wilslewe en die gedagtelewe staan onder Satan se verderflike invloed. Paulus wys hier op twee vorme van die menslike wil: die wil van die vlees en die wil van die gedagtes (Ef. 2:3). Met die wil van die vlees bedoel die apostel die sondes van sinlike aard: sedeloosheid, ontug, oneerlike praktyke en gemene dade. Die sondes van die wil van die gedagtes lê meer op die verstandelike, intellektuele vlak, soos trots, hoogmoed, haat, valse ambisie, bitterheid, naywer en wraakgevoelens. Op hierdie terreine laat die duiwel sy invloed geld.

Die duiwel, as vors van die duisternis, doen hom soms voor as 'n engel van die lig (2 Kor. 11:14). Hy verlei sy volgelinge om dit te laat voorkom asof hulle die wil van God doen (2 Kor. 11:15). Trouens, die duiwel probeer op alle moontlike maniere om Christus na te boots. Christus is die inkarnasie, die vleeswording van die waarheid (Kuyper, 1923:93). So is die Satan besig om die geboorte van 
Christus na te boots. Paulus beskryf die karikatuur van die vleeswording van die waarheid as die vleeswording van die leuen. Satan is die wettelose mens, die antichris wat Paulus as die verskyning van die wettelose beskryf (2 Tess. 2:9).

Die duiwel en sy demone kan besit neem van 'n mens (Bietenhard, 1975:449-453). So het die duiwel in Judas ingevaar (Joh. 13:27). Die demone is aan Satan ondergeskik. Hulle is sy bose engele (Mark. 3:20; Ef. 2:2). Die Evangelies verwys na baie mense wat deur die duiwel besete was (White, 1930:207-209). 'n Mens is slegs veilig teen die aanslae van die Bose as hy by Christus skuil en sý wapenrusting dra (Ef. 6:10-12; vgl. Joubert \& Van der Watt, 1993:78-92).

\section{Konflikte tussen goeie en slegte engele}

In die Bybel word konflikte tussen goeie en bose engele beskryf. Twee voorbeelde hiervan word aangetoon. Die voorbeelde verwys na twee oorloë op 'n hoë vlak. By albei was die duiwel self betrokke. Aan die ander kant van die oorlogsfront was daar twee aartsengele.

In die brief van Judas word 'n konflik tussen 'n goeie engel en 'n bose engel beskryf. Hierdie stryd was nie maar net 'n oorlog tussen engele en demone van 'n laer rangorde nie. Die aartsengel, Migael, het met die duiwel gestry (Jud. :9). Dit was 'n oorlog op die hoogste vlak van die engeleryk. Uit 'n apokriewe geskrif, Die hemelvaart van Moses, haal Judas die stryd tussen die twee magtige geeste aan (Green, 1976:165). Die konflik het gegaan oor die liggaam van Moses. Toe Moses gesterf het op die berg Nebo was God self die "lyksbesorger". Moses se liggaam sou nie tot ontbinding oorgaan nie. Die duiwel wou Moses se liggaam hê op grond van die feit dat Moses 'n moordenaar was (Eks. 2:11). In sy twisgesprek met die duiwel het Migael dit nie gewaag om die duiwel te beledig en te veroordeel nie. Hy gee die duiwel oor aan God wat hom sal straf.

Die tweede konflik speel hom af in die hemel (Op. 12:7). Daar vind ' $n$ tweegeveg in die hemel plaas. Die aartsengel, Migael, is die eerste hoofrolspeler. Hy voer oorlog met die rooi draak, die tweede hoofrolspeler. Die groot vuurrooi draak met sy sewe koppe en tien horings (Op. 12:3) is dieselfde as die slang in die paradys (Gen. 3:1; Op. 12:9). Hy is die leier van alle bose magte op aarde (Van de Kamp, 2000:286). Migael, die opperbevelhebber van die hemelse leërmagte, voer oorlog met die groot generaal van die demoniese magte (Mazzaferri, 1989:95). Die duiwel ly 'n verpletterende neerlaag. Hy word uit die hemel uitgegooi. Hy is op die aarde gegooi 
en sy engele saam met hom. Die aarde het nou die operasiebasis van die duiwel en sy bose engele geword. Sy aanvalle is veral gemik op die volgelinge van Jesus (Op. 12:17).

Die volgelinge van Jesus mag vertrou dat God, waar nodig, sy engele sal stuur om hulle te beskerm (Ps. 91). Hulle moet egter op hulle pos bly vanweë die listige aanslae van die duiwel (Ef. 6:10). Die stryd wat gevoer moet word, is teen elke mag en gesag, teen elke gees wat heers in hierdie sondige wêreld, teen elke bose gees in die lug (Ef. 6:12). Paulus deel die vyand in drie groepe in: owerhede, magte en heersers van die duisternis. Paulus dui waarskynlik hier nie verskillende range van die vyandige leërmag aan nie. Hy beskryf die bose magte telkens vanuit ' $n$ ander gesigshoek om aan te toon hoe gewelddadig hulle is. Die owerhede

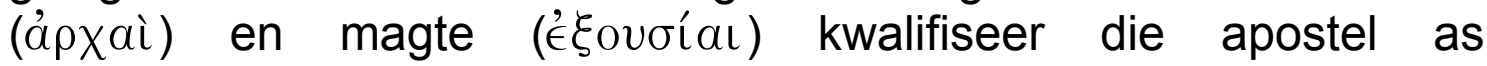
wêreldbeheersers (тоن̀s кобнокра́тораs) van die duisternis. Vanuit hulle skuilplek handel hulle met uiters gevaarlike wapens: brandpyle van die Bose (Ef. 6:16). Dit is pyle in die vorm van 'n leuenagtige tong, 'n gevaarlike influistering tot hoogmoed, 'n verleidelike aanbod tot sonde. Dit alles is deur die vyand bedoel om te brand en te vernietig (Foulkes, 1975:176).

Die gelowiges word deur goeie engele gedien (Hebr. 1:14), maar hulle moet tegelyk teen bose engele beskerm word. Die gelowige moet self deelneem aan die stryd teen bose magte wat hom/haar omring. In die stryd teen al die bose engele is 'n goeie wapenrusting nodig. Paulus beskryf in Efesiërs 6 die Christensoldaat. Die apostel gebruik die beeld van 'n antieke soldaat wat met sy volle wapenrusting gereed is vir die oorlog. In sy mondering is daar twee onderdele wat van die grootste belang is: die skild van die geloof en die swaard van die Gees (Ef. 6:16-17). Herodotus vertel dat die Perse by die beleëring van Athene groot skilde gebruik het wat met nat velle oorgetrek was om die brandende pyle van die vyand af te weer (Floor, 1998:207). So moet die Christensoldaat ter verdediging met die skild van die geloof die brandpyle van die Bose afweer. Die aanvalswapen is die swaard, 'n kort wapen ( $\mu a ́ x \alpha \iota \rho \alpha)$ wat gebruik is in 'n geveg van man teen man. Die swaard van die Gees is die Woord van God (Ef. 6:17). Die Woord van God is hier die woord wat gespreek word $(\hat{\rho} \hat{\eta} \mu \alpha)$. Die geloofsgetuienis van 'n Christen is met die bystand van die Heilige Gees 'n magtig wapen in die stryd teen die bose engele. 


\section{Gevolgtrekkings}

Uit die kort oorsig wat hierdie artikel bied, blyk dit dat die Bybel komplekse inligting bied oor engele, Satan en bose magte. 'n Beter begrip van die hele engeleryk is nodig om die konteks te skets vir besinning oor demoongekweldheid.

Uit die historiese oorsig blyk dit hoe teologiese tendense 'n direkte invloed op mense se denke oor engele uitoefen. Standpunte wissel van vergoddeliking, spekulering, romantisering en ontkenning van engele. In die lig van hierdie tendense blyk die noodsaaklikheid van 'n besinning oor engele vanuit die Bybel.

Uit die Bybel blyk dit dat engele deur God geskape is en dat 'n bepaalde plek en spesifieke take aan hulle toegeken is. Gevolglik is dit verkeerd om engele te vergoddelik, oor hulle te spekuleer, hulle te romantiseer of te ontken dat hulle bestaan. Engele het ' $n$ bepaalde taak in die skepping wat deur God aan hulle opgedra is. Van die engele het teen God in opstand gekom oor die posisie wat aan hulle toegeken is. Dit het gelei tot 'n sondeval in die engeleryk. Satan staan aan die hoof van hierdie bose ryk en gebruik demone as sy onderdane om kwaad te stig. Die inwerking van die bose is op verskeie terreine van die lewe herkenbaar, van afvalligheid en wetteloosheid in die algemeen, tot so veel as demoongekweldheid. Demoongekweldhied lei tot konflik tussen die goeie en bose engele. Goeie engele moet die eer van God en die veiligheid van gelowiges teen die bose aanslae beskerm.

\section{Geraadpleegde bronne}

AQUINAS, THOMAS. 1991. Summa Theologiae. Westminister: Christian Classics. Trans. T. McDermott.

AUGUSTINUS. 1947. De staat Gods. Kampen: Kok. Vert. J. Wytzes.

BARKER, M. 1992. The great angel: a study of Israel's second God. Westminster: John Knox.

BARTH, K. 1936. Kirchliche Dogmatik. III, 3. Zürich: Evangelischer Verlag.

BAVINCK, H. 1928. Gereformeerde dogmatiek. Kampen: Kok.

BERKHOF, H. 1952. Christus en de machten. Callenbach: Nijkerk.

BIETENHARD, H. 1975. Daimonion. (In Brown, C., ed. Dictionary of New Testament. Vol. 1. Exeter: The Paternoster Press. p. 449-453.)

BLAUW. J. s.a. Gezanten van de hemel. Baarn: Bosch \& Keuning.

BULTMANN, R. 1984. New Testament and mythology and other basic writings. Minneapolis: Fortress.

CALVYN, J. 1972 [1549]. Zendbrief aan de Hebreën. Goudriaan: De Groot.

CALVYN, J. 1980 [1559]. Institusie. Potchefstroom: Calvyn-Jubileumboekefonds. Vert. H.W. Simpson. 
DE GRAAFF, L.F. 2004. De verdwijning der engelen uit kerk en teologie: engelen. oude voorstellingen en nieuwe ervaringen. Zoetermeer: Boekencentrum.

FLOOR, L. 1998. Efeziërs: eén in Christus. Kampen: Kok.

FOULKES, F. 1975. The epistle of Paul to the Ephesians. Grand Rapids: Eerdmans.

FOX, R. 1997. Can there be a reason to believe in angels and demons? Downside Review, 115:112-138.

GODET, F. 1986. Das Evangelium des Lukas. Giessen: Brockhaus.

GREEN, M. 1976. The second epistle of Peter and the epistle of Jude. Grand Rapids: Eerdmans.

HARDER, G. 1978. Noèma (In Brown, C., ed. Dictionary of New Testament theology. Vol. 3. Exeter: Pater Noster. p. 125.)

HEYERS, M.C. 1984. The meaning of creation: Genesis and modern science. Atlanta: John Knox.

HUMAN, D. 1997. Engele en ander hemelse wesens: enkele pennestrepe vanuit die Ou Testament. (In Joubert, S. \& Van der Watt, J.G., reds. Hy sal sy engel voor jou uitstuur: 'n ontdekkingstog deur die Bybel op soek na engele. Vereeniging: Christelike Uitgewersmaatskappy. p. 32-52.)

JOUBERT, S. 1997a. 'n Kykie na wat die Nuwe Testament oor engele sê. (In Joubert, S. \& Van der Watt, J.G., reds. Hy sal sy engel voor jou uitstuur: 'n ontdekkingstog deur die Bybel op soek na engele. Vereeniging: Christelike Uitgewersmaatskappy. p. 54-65.)

JOUBERT, S. 1997b. "Word ons eendag engele?" en ander vrae wat mense vandag vra. (In Joubert, S. \& Van der Watt, J.G., reds. Hy sal sy engel voor jou uitstuur: 'n ontdekkingstog deur die Bybel op soek na engele. Vereeniging: Christelike Uitgewersmaatskappy. p. 103-111.)

JOUBERT, S. \& Van der Watt, J. 1993. Satan ontbloot! Vereeniging: Christelike Uitgewersmaatskappy.

KUYPER A. 1923. De engelen Gods. Kampen: Kok.

LAMBERT, W.G. 1975. The cosmology of Sumer and Babylon. (In Blacker, C. \& Loewe, M., eds. Ancient cosmologies. London: Unwin. p. 55-59.)

LE ROUX, J. 1997. Engele en die Ou Testament. (In Joubert, S. \& Van der Watt, J.G., reds. Hy sal sy engel voor jou uitstuur: 'n ontdekkingstog deur die Bybel op soek na engele. Vereeniging: Christelike Uitgewersmaatskappy. p. 11-31.)

LEAHY, F.S. 1990. Satan cast out: a study in biblical demonology. Edinburgh: The Banner of Thruth.

LOUTH, A. 1989. Denys the Areopagite. Wilton: Morehouse-Barlow.

MAZZAFERRI, F.D. 1989. The genre of the Book of Revelation from a sourcecritical perspective. Berlin/New York. (Beischrift Zeitschrift für die neutestamentliche Wissenschaft, 54.)

NOLL, S.F. 1998. Angels of light, powers of darkness: thinking Biblically about angels, Satan and principles. Illenois: InterVarsity.

RIDDERBOS, H.N. 1967. De pastorale brieven. Kampen: Kok.

SCHEIERMACHER, F. 1928. The Christian faith. Edinburgh: Clark.

SCHILDER, K. 1929. Tusschen "Ja" en "Neen". Kampen: Kok.

SCHOEMAN, E. 1997. Reis met engele. Kaapstad: Human \& Roussau.

SELDERHUIS, H.J. 2001. Je bent een engel. Barneveld: Vuurbaak.

SMART, N. 1984. The religious experience of mankind. New York: Scribner's. 
STANDER, H. 1997. Wat het die ou kerkvaders oor engele gesê? (In Joubert, S. \& Van der Watt, J.G., reds. Hy sal sy engel voor jou uitstuur: 'n ontdekkingstog deur die Bybel op soek na engele. Vereeniging: Christelike Uitgewersmaatskappy. p. 66-91.)

STOLK, H. 1964. Keur uit de tafelgesprekken van dr. Maarten Luther. Dordrecht: Van de Tol.

STRAUSS, D.F. 1906 [1880]. The life of Jesus. London: Sonnenschein.

VAN AARDE, A.G. 1987. Demonoly in New Testament times. (In De Villiers, P.G.R., ed. Like a roaring lion: essays on the Bible, the church and demonic powers. Pretoria: UNISA. p. 22-37.)

VAN DE KAMP, H.R. 2000. Openbaring: profetie vanaf Patmos. Kok: Kampen.

VAN DER WATT, J. 1997. In watse wêreld vlieg die engele oral rond? (In Joubert, S. \& Van der Watt, J.G., reds. Hy sal sy engel voor jou uitstuur: 'n ontdekkingstog deur die Bybel op soek na engele. Vereeniging: Christelike Uitgewersmaatskappy. p. 92-102.)

VAN OYEN, H. 1954. Christus de hogepriester: de brief aan de Hebreën. Callenbach: Nijkerk.

VILJOEN, F.P. 1986. Die betekenis van thronoi, kuriotetes, archai en eksousia in Kolossense 1:16. Potchefstroom: PU vir CHO. (M.A.-verhandeling.)

VILJOEN, F.P. 2002. Die strategiese funksie van die Christus-himne in Kolossense 1:13-20. In die Skriflig, 36(1):67-90.

VILJOEN, F.P. 2003. Die betekenis en funksie van die himnes in Openbaring 411. Acta Theologica, 23(1):213-237.

VORGRIMLER, H. 2001. Engel, Erfahrungen göttlicher Nähe. Stuttgart: Herder.

WHITE, A. 1930. The nature of angels. London: Hodder \& Stoughton.

WINK, W. 1986. Unmasking the powers: the invisible forces that determine human existence. Philadelphia: Fortress.

\section{Kernbegrippe:}

demoon

duiwel/Satan

engel

Heilige Gees

Key concepts:

angel

demon

devil/Satan

Holy Spirit 